\title{
Assimilation of surface Active Agents by Microorganisms
}

\author{
YOJI WACHI
}

\begin{abstract}
A Study was made on the possible assmilation of nonionic surfactants by various microorganisms. Microorganisms used in this study were isolated from cosmetic products.

Among the 60 tested nonionic surfactants, those of pluronic type were not utilized by fungi, yeasts and bacteria. The reason for this can be attributed to the composition of the surfactants which is made up in combination between propylene glycol and ethylene glycol. However, other ester and ether-ester type nonionic surfactants were found to be utilized as a sole source of carbon by microorganisms.
\end{abstract}

Especially, Psuedomonas aeruginosa (wild type No.16) was noted to demonstrate a strong ability to assimilate most of the tested surfactants except those of pluronic type.

In regard to the ability of assimilation, the microorganisms isolated from cosmetic products were generally superior to the type strains.

\section{1. 緒言}

活性剤は一般にアニオン活性剤, カチオン活性剤, 両 性活性剂, 非イオン型活性剤の 4 つに分類される。ここ でこれら活性剤と微生物の関連を考えた場合, カチオン 活性剤, 両性活性はそれらの殺菌力が問題となる。從っ て資化性を考元場合, 問題となるのはアニオン又はノ ニオン活性剤である。アニオン活性剤は主に洗浄剤とし て広く用いられているが, 河川の污染などと関連してそ の廃棄の問題から生分解性（資化性）についていろいる 検討されている。そこで化粧品原料として活性剤の資化 性を考皇た場合，ノニオン活性剤が中心となる。

それ故, 本研究では活性剤群としてはノニオン活性剂 を選定し，化粧品から分離された微生物を用いェステル 型を中心とした非イオン型界面活性剤約 60 種に対する資 化性の検討を行ったのでここに報告する。

株) 資生堂研究所.

SHISEIDO LABORATORIES.

\section{2. 使用界面活性剂}

○ポリオキシェチレン硬化ヒマシ油誘導体

$\mathrm{HC}-5$, HC-10, HC-30, HC-60

○ポリオキシェチレン硬化ヒマシ油モノイソステアレー

卜

RWIS 105, RWIS 110, RWIS 140, RWIS 150.

○ポリオキシェチレンオレイン酸エステル

$\mathrm{C}_{17} \mathrm{H}_{33} \mathrm{CO} \cdot \mathrm{O}\left(\mathrm{CH}_{2} \mathrm{CH}_{2} \mathrm{O}\right)_{n-1} \mathrm{CH}_{2} \mathrm{CH}_{2} \mathrm{OH}$

$\mathrm{OE}-6 ; \mathrm{OE}-10$

○ポリオキシェチレンステアリン酸エステル

$\mathrm{C}_{17} \mathrm{H}_{35} \mathrm{CO} \cdot \mathrm{O}\left(\mathrm{CH}_{2} \mathrm{CH}_{2} \mathrm{O}\right)_{n-1} \mathrm{CH}_{2} \mathrm{CH}_{2} \mathrm{OH}$

Em. 810, Em. 820

○ポリエチンングリコールジステアレート

$\mathrm{C}_{17} \mathrm{H}_{35} \mathrm{CO} \cdot \mathrm{O}\left(\mathrm{CH}_{2} \mathrm{CH}_{2} \mathrm{O}\right)_{\mathrm{n}-1} \mathrm{CH}_{2} \mathrm{CH}_{2} \mathrm{O} \cdot \mathrm{OCC}_{17} \mathrm{H}_{35}$

$200 \mathrm{dī}-\mathrm{S}, 300 \mathrm{dī}-\mathrm{S}, 400 \mathrm{dī}-\mathrm{S}, 600 \mathrm{dī}-\mathrm{S}$

○ポリエチンングリコールジォレエート

$\mathrm{C}_{17} \mathrm{H}_{33} \mathrm{CO} \cdot \mathrm{O}\left(\mathrm{CH}_{2} \mathrm{CH}_{2} \mathrm{O}\right)_{n-1} \mathrm{CH}_{2} \mathrm{CH}_{2} \mathrm{O} \cdot \mathrm{OCC}_{17} \mathrm{H}_{33}$ 200 dì-O, 300dī-O, 400ī-O, 600dī-O 
○プロピレングリコールモノェステル

$\begin{array}{lll}\mathrm{CH}_{3} & \text { R } \cdots \mathrm{C}_{17} \mathrm{H}_{35} & \text { P.G.S. } \\ \mathrm{CHOH}_{\mathrm{CH}_{2} \mathrm{O}}^{\mathrm{C}_{\mathrm{O}} \mathrm{OCR}} & \mathrm{R} \cdots \mathrm{C}_{17} \mathrm{H}_{33} & \text { P.G.O. }\end{array}$

○プロピレングリコールジェステルル

$\begin{array}{lll}\mathrm{CH}_{3} & \text { R... } \mathrm{C}_{17} \mathrm{H}_{35} & \text { P.G. dì-S } \\ \mathrm{CHO} \cdot \mathrm{OCR} & \text { R... } \mathrm{C}_{17} \mathrm{H}_{33} & \text { P.G. dì-O } \\ \mathrm{CH}_{2} \mathrm{O} \cdot \mathrm{OCR} & & \end{array}$

○ポリオキシエチレンラウリルアルコールエーテルイソ ステアレート

$\mathrm{C}_{12} \mathrm{H}_{2 \overline{5}} \mathrm{O}\left(\mathrm{CH}_{2} \mathrm{CH}_{2} \mathrm{O}\right)_{\mathrm{n}-1} \mathrm{CH}_{2} \mathrm{CH}_{2} \mathrm{O} \cdot \mathrm{OCC}_{17} \mathrm{H}_{35}$ LWIS-2, LWIS-5, LWIS-8, LWIS-10

○ポリオキシェチレンラウリルアルコールエーテルステ アレート

$\mathrm{C}_{12} \mathrm{H}_{25} \mathrm{O}\left(\mathrm{CH}_{2} \mathrm{CH}_{2} \mathrm{O}\right)_{\mathrm{n}-1} \mathrm{CH}_{2} \mathrm{CH}_{2} \mathrm{O} \cdot \mathrm{OCC}_{17} \mathrm{H}_{35}$

LWS-3, LWS-5, LWS-8, LWS-10

○ポリオキシェチレンオクチルフェノールエーテルイソ ステアレート

$\mathrm{C}_{8} \mathrm{H}_{17} \backslash \mathrm{O}\left(\mathrm{CH}_{2} \mathrm{CH}_{2} \mathrm{O}\right)_{\mathrm{n}-1} \mathrm{CH}_{2} \mathrm{CH}_{2} \mathrm{O} \cdot \mathrm{OCC}_{17} \mathrm{H}_{35}$ ○ポリオキシェチレングリセロールトリステアレート

$\mathrm{CH}_{2} \mathrm{O}\left(\mathrm{CH}_{2} \mathrm{CH}_{2} \mathrm{O}\right)_{\mathrm{a}-1} \mathrm{CH}_{2} \mathrm{CH}_{2} \mathrm{O} \cdot \mathrm{OCC}_{17} \mathrm{H}_{35}$
$\mathrm{CHO}\left(\mathrm{CH}_{2} \mathrm{CH}_{2} \mathrm{O}\right)_{b-1} \mathrm{CH}_{2} \mathrm{CH}_{2} \mathrm{O} \cdot \mathrm{OCC}_{17} \mathrm{H}_{35}$
$\mathrm{CH}_{2} \mathrm{O}\left(\mathrm{CH}_{2} \mathrm{CH}_{2} \mathrm{O}\right)_{\mathrm{c}-1} \mathrm{CH}_{2} \mathrm{CH}_{2} \mathrm{O} \cdot \mathrm{OCC}_{17} \mathrm{H}_{35}$

GWS-303, GWS-304, GWS-305, GWS-306 ○スパン

Span 20 モノラウリン酸ソルビタン

Span 40 モノパルミチン酸ソルビタン

Span 60 モノステアリン酸ソルビタン

Span 80 モノオレイン酸ソルビタン

○ツィーン

スパンにェチレンオキサイドが 20 モルずつ付加された もの。

Tween 20 Tween 40, Tween 60, Tween 80 ○ポリオキシェチレントリメチロールプロパントリステ アレート

$$
\mathrm{CH}_{3} \mathrm{CH}_{2} \mathrm{C}-\stackrel{-\mathrm{CH}_{2} \mathrm{O}\left(\mathrm{CH}_{2} \mathrm{CH}_{2} \mathrm{O}\right)_{\mathrm{a}-1} \mathrm{CH}_{2} \mathrm{CH}_{2} \mathrm{O} \mathrm{CH}_{2} \mathrm{O}-\mathrm{OCC}_{17} \mathrm{H}_{35}}{\mathrm{CH}_{2}}
$$

TPS 303, TPS 305, TPS 308, TPS 310

○プルロニック

$\mathrm{HO}\left(\mathrm{C}_{2} \mathrm{H}_{4} \mathrm{O}\right)_{\mathrm{a}}-\left(\mathrm{C}_{3} \mathrm{H}_{6} \mathrm{O}\right)_{\mathrm{b}}-\left(\mathrm{C}_{2} \mathrm{H}_{4} \mathrm{O}\right)_{\mathrm{c}} \mathrm{H}$

プルロニックは親水性の少いプロピレングリコールを
疎水基としてエチンンオキサイドを附加した非イオン 界面活性剂

L 31, L 61, L 62, L 64, L 101, F 38, F 68, F 83, F 108

以上53種である。すべて市販品（日本エマルジョン $\mathrm{K}$ $\mathrm{K}$, スパン, ツィーンは東京化成, プルロニックは旭電 化）を用い特別な精製は行わなかった。市販のノニオン 界面活性剤は付加されているエチレンオキサイドのモル 分布が広く複雑な混合物であり分析も種々の問題がある ので, 資化性の検討も活性剂の減少の確認は行わず菌の 增殖, それにともなう $\mathrm{pH}$ 変化などに資化性の基準を求 めた。

\section{3. カビによる界面活性剤の資化}

\section{1. 供試菌}

$\left.\begin{array}{ll}\text { O-2 } & \text { Penicillium 属 } \\ \text { O-4 } & \text { Aspergillus 属 } \\ \text { Q-2 } & \text { Penicillium 属 }\end{array}\right\}$ 製品分離菌

Penicillium notatum Aspergillus niger 標準菌株

製品分離菌 15 種の中から 3 種えらび，それに標準菌 株 2 種を加え， 5 種のカビを選定した。

\section{2. 培養法と資化性の判定}

Table 1 に示した培地 $20 \mathrm{ml}$ を $50 \mathrm{ml}$ 三角フラスコに 入れオートクレーブで隇菌する。冷却後あらかじめ前培 養したカビの胞子懸濁水を一定量接種し， $30^{\circ} \mathrm{C}$ で 3 週 間静置培養した。

TabIe 1 Composition of media

\begin{tabular}{lcr}
\hline \multicolumn{2}{c}{ For Yeasts and Fungi } & For Bacteria \\
\hline $\mathrm{KH}_{2} \mathrm{PO} 4$ & $2.3 \mathrm{~g}$ & $0.5 \mathrm{~g}$ \\
$\mathrm{~K}_{2} \mathrm{HPO} 4$ & $0.7 \mathrm{~g}$ & $2.5 \mathrm{~g}$ \\
$\mathrm{MgSO}_{4} \cdot 7 \mathrm{H}_{2} \mathrm{O}$ & $0.3 \mathrm{~g}$ & $0.3 \mathrm{~g}$ \\
$\mathrm{CaCl}_{2}$ & $0.3 \mathrm{~g}$ & $0.3 \mathrm{~g}$ \\
$\mathrm{NaCl}$ & $0.3 \mathrm{~g}$ & $0.3 \mathrm{~g}$ \\
$\left(\mathrm{NH}_{4}\right)_{2} \mathrm{SO}_{4}$ & $3.0 \mathrm{~g}$ & $3.0 \mathrm{~g}$ \\
$\mathrm{~S} . \mathrm{A} . \mathrm{A}$. & $10.0 \mathrm{~g}$ & $10.0 \mathrm{~g}$ \\
Water & 1000 & 1000 \\
$\mathrm{pH}$ & $6.8-7.0$ & $5.5-5.7$ \\
\hline
\end{tabular}

菌が生育すればその菌は唯一の炭素源として活性剂を 利用出来ることがわかる。アニオン活性剂などの生分解 性の試験では, $100 \mathrm{ppm}$ 位の濃度で行われているが，こ こでは $1 \%(10000 \mathrm{ppm})$ である。

培湌中, 経時的に菌糸, 胞子囊の生育状態の観察, 3 週 
間目の pH 測定などを行った。

これらを基準にして資化性の度合を Table 2 のよう に 5 ランクにわけて判定した。

TabIe 2 Variation of assimilation by fugi

\begin{tabular}{cc}
\hline \hline Liquid Culture & $30^{\circ} \mathrm{C}, 3$ Weeks \\
ogrowth of mycelium, sporulation \\
OpH-change of medium by time \\
Rank & pH-change \\
0 : no assimilation & 5.90 \\
1 : poor assimilation & $5.50 \sim 5.90$ \\
2 : fair assimilation & $4.50 \sim 5.50$ \\
3 : good assimilation & $3.50 \sim 4.50$ \\
4: excellent assimilation & $2.70 \sim 3.50$ \\
\hline
\end{tabular}

Table 1 に示した培地組成より活性剂学除いたものを 0ランク，活性剤のかわりにグルコースを添加したもの を4ランクとした。

\section{3. 結果}

SP. 60 と TW 60 に対する Asp. niger の生育を Fig.1 に示した。SP 60, TW 60 ともに菌系の生育は 久られるが，TW 60 の方が胞子囊の着生もよく SP 60

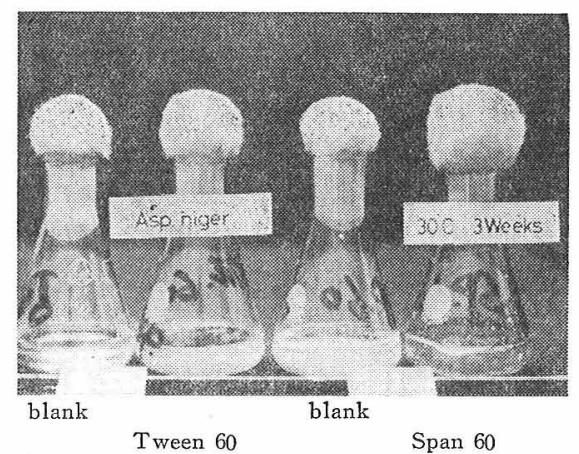

Fig. 1 Growth of Asp. niger

に比べTW 60 の方がよく資化される。（SP 60 は 2 ラン ク，TW 60 は 3 ランク）スパンにエチレンオキサイド が 20 モル付加されたツィーンの方が資化性がよいとい ら傾向は Aspergillus 属だけでなく, 他のカビについて も認められた。

次にッィーンに対する 3 種のカビ（0-2，0-4. Asp. niger）の生育を示すと Fig.2，Fig.3，Fig.4，のよう になる。0-2は，TW 20 に若干胞子囊が着生する以外は

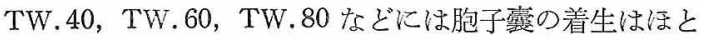
んど喼められなかった。しかし菌糸の発育はTW 80 で はよく $\mathrm{pH}$ の低下も認められた。(TW.80, 3 ランク，T

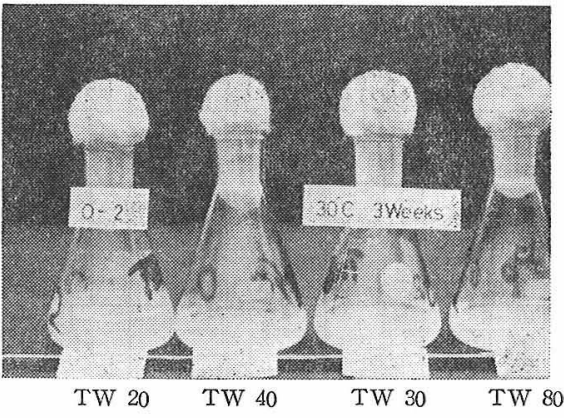

Fig. 2 Growth of $0-2$

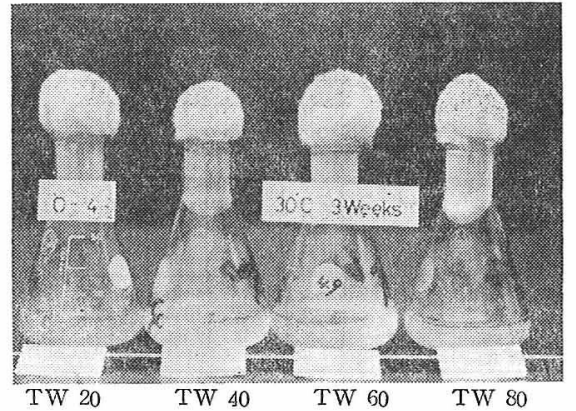

Fig. 3 Growth of $0-4$

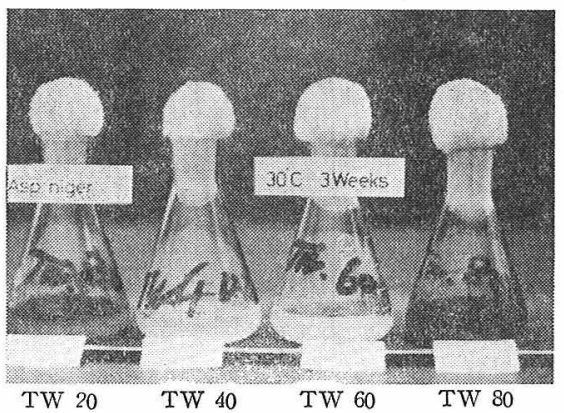

Eig. 4 Growth of Asp. niger

W 20 2 ランク, TW 60 1 ランク), 0-4 (Asp.flavus) はいずれのものにも菌系の発育がよく, 胞子囊の着生も みられた。生育にともなら pH の変化も大きく,どれる よく資化された。特に TW 80 は pH 3.20 迄低下しラン ク 4, あとはランク 3 , Asp. niger は 0-4 と同様, 菌系 の発育, 咆子囊の着生もよく, どれもよく資化した。

以上のようにして判定したカビによる資化性のランク を示すと Table 3 のようになる。Table 3 は縦に活性 剤, 横に菌の種類とランクをとった。従って横に長い方 がランクが高く，よく資化されることを示す。 
TabIe 3 Assimilation of S.A.A. by Fungi

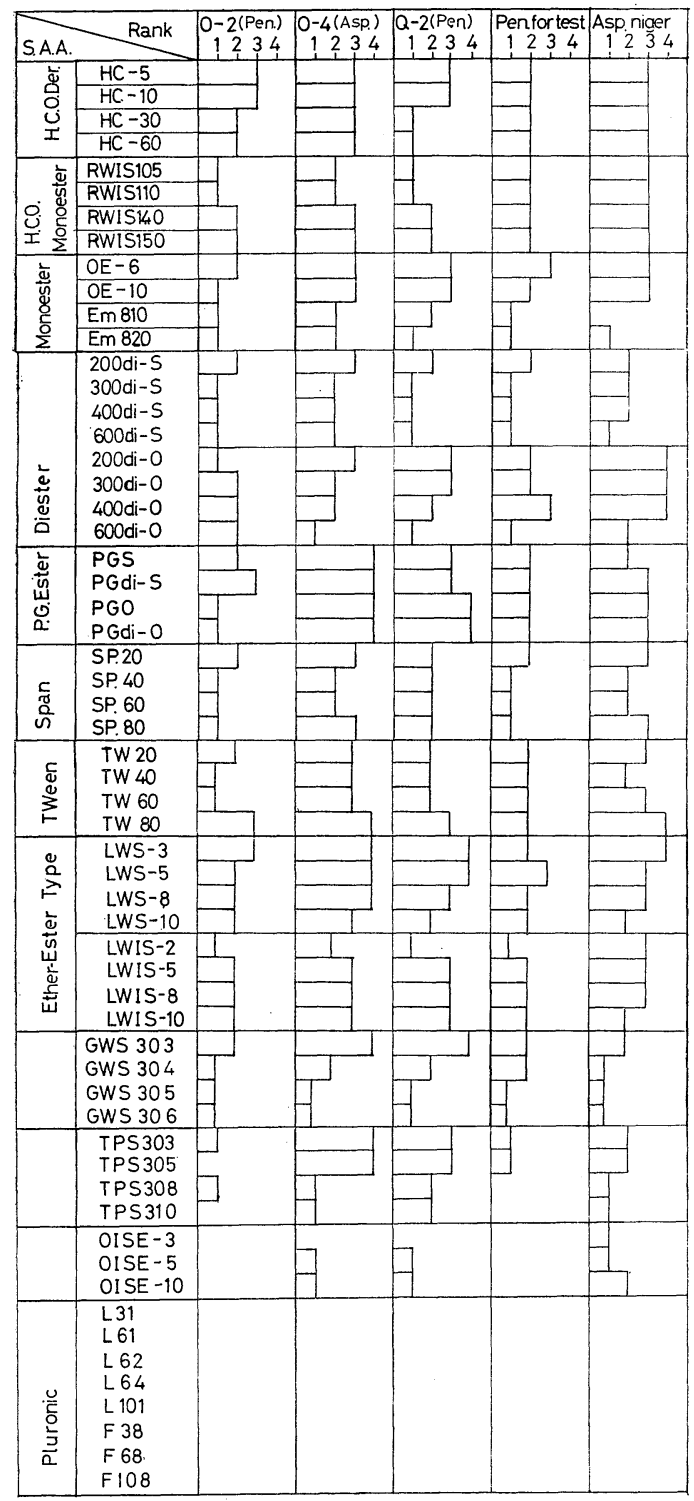

Table 3 からわかるように, P.O.E.硬化ヒマシ油誘 導体（H.C.O.系）は全体的にどれもよく資化された。 H.C.O.系にイソステアリン酸がついた P.O.E. 硬化ヒ マシ油モノイソステアレートは資化されるが，H.C.O. 系に比べると資化されにくくなっている。P.O.E. 脂肪 酸モノエステルはオレイン酸のエステルは資化されたが ステアリン酸のエステルは資化されにくかった。

P.O.E. 脂肪酸ジェステルも, オレイン酸のジェステル はよく資化されたがステアリン酸のジェステルの資化性
は悪かった。

プロピレングリコールモノ, ジェステルはモノェステ ル, ジェステルともによく資化された。

スパンは SP 20> SP 80> SP 60>SP 40 の順によ く資化された。スパンにェチレンオキサイドが20モル付 加されたツィーンは TW 80> TW 20> TW 60> TW 40の順によく資化された。全体的にスパンょりもよく資 化された。

P.O.E.ラウリルアルコールエーテル ステアレートは 4 種ともよく資化されたが付加モル数が増すと資化性が 悪くなる傾向がみられた。

P.O.E.ラウリルアルコールエーテルイソステアレー トもよく資化された。

P.O.E.グリセロールトリステアレートはェチレンオ キサイドが 3 モル付加された GWS 以外は注とんど資 化されなかった。

P.O.E.トリメチロールプロパントリステアレートは 今迄の傾向とは少し異なり 0-4，Q-2 など製品から分離 されたカビによって資化されたが標準菌株による資化性 は悪かった。この系もエチレンオキリイドの付加モル数 が增すに従って資化性は悪くなった。P.O.E.オクチル フェノールェーテルイソステアレートは 5 種のカビによ りほとんど資化されなかった。プルロニックは 5 種のカ ビに全く資化されなかった。

以上，カビによる資化性をまとめてみるとP.O.E. 硬 化ヒマシ油誘導体, プロピレングリコールモノ, ジェス テル，P.O.E.ラウリルアルコールェーテルイソステア レート，P.O.E. ラウリルアルコールェーテルステアレ 一トなどの活性剤はよく資化された。一方 P.O.E.ス テアリン酸ジェステル，P.O.E. グリセロールトリステ アレート, P.O.E. トリメチロールプロパントリステア レート，プルロニックなぞは資化されにくかった。エチ レンオキサイドの付加モル数が増すに従って資化性が悪 くなる傾向のみら机る活性剂としては，P.O.E. 脂肪酸 ジェステル，P.O.E. 硬化ヒマシ油誘導体，P.O.E. グ リセロールトリステアレート, P.O.E. トリメチロール プロパントリステアレートなどがある。

又, 菌株的には Penicillium 属のカビよりAspergillus 属のカビの方が資化性がよかった。そして標準菌株より 製品分離カビの方が全体的に資化性がよかった。

\section{4. コウボによる界面活性剛の餈化}

\section{1. 供試菌}


$\begin{array}{ll}\text { SY-10 } & \text { Candida 属 } \\ \text { SY-16 } & \text { Candida 属 }\end{array}$ 製品分離菌 製品分離菌16種の中から 2 種選定した。

\section{2. 培養法と資化性の判定}

Table 1 に示した培地 $100 \mathrm{ml}$ を 500 $\mathrm{m} \ell$ 振とうフラスコに入れ，オートクレー ブで滅菌，冷却後あらかじめ前培養した 菌の懸濁水を一定量接種し, $30^{\circ} \mathrm{C}, 120$ 回 /分の振とう条件で 3 週間培養した。 $\mathrm{pH}$ 経時変化, 生菌数, 3 週間目 の乾燥菌体 重量などを測定した。乾燥菌体重量は培 養液を3500回/分，10分遠心分離して集 菌し、アセトン $60 \mathrm{~m} \ell$ で洗浄後エーテル $40 \mathrm{~m} \ell て ゙ 2$ 回洗浄した。遠心分離して集菌 し真空デシケーター中で $4 \sim 5$ 日乾燥後 科量し乾燥菌体重量とし六。

資化性の判定

TabIe 4 Variation of assimilation by yeast

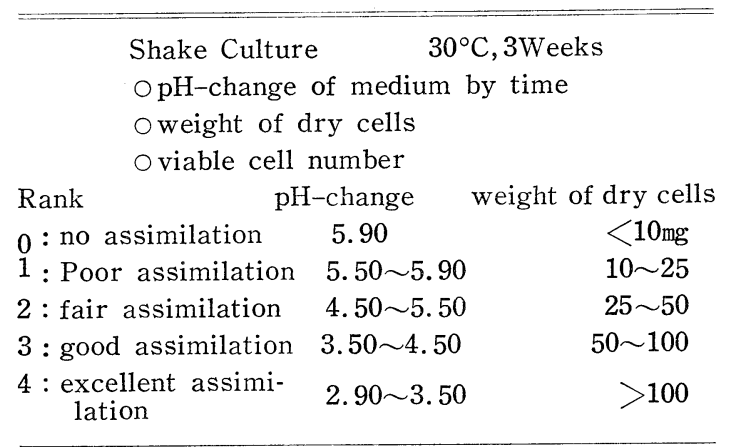

$\mathrm{pH}$ 変化, 乾燥菌体重量, 生菌数などのデーターから

TabIe 4 に示寸様に 5 ランクにわけて判定，一例とし て P.O.E. 硬化ヒマシ油誘導体の SY-16 の資化性につ いて示すと Table 5 のようになる.

Table 5 Assimilation of H.C.O. derivatives by SY-16

\begin{tabular}{|c|c|c|c|c|c|c|c|c|c|}
\hline \multirow{2}{*}{ S.A.A. } & \multicolumn{4}{|c|}{$\mathrm{PH}$} & \multicolumn{3}{|c|}{$\begin{array}{r}\text { viable ce11 numbers } \\
(\text { cel1s/m1) }\end{array}$} & \multirow{2}{*}{$\begin{array}{c}\text { weight of } \\
\text { dry cells } \\
(21 \text { days, } \\
\text { mg })\end{array}$} & \multirow{2}{*}{ Rank } \\
\hline & 0 & 3 & 7 & 14 & 0 & 7 & 14 & & \\
\hline $\mathrm{HC}-5$ & 6.00 & 5.82 & 4.20 & 3.00 & $1.5 \times 10^{4}$ & $2.0 \times 10^{8}$ & $7.7 \times 10^{5}$ & 127.3 & 4 \\
\hline $\mathrm{HC}-10$ & 6.00 & 5.80 & 5.72 & 5.32 & $1.5 \times 10^{4}$ & $2.4 \times 10^{7}$ & $6.2 \times 10^{7}$ & 42.8 & 2 \\
\hline $\mathrm{HC}-30$ & 6.00 & 5.82 & 5.80 & 5.70 & $1.5 \times 10^{4}$ & $3.3 \times 10^{5}$ & $5.7 \times 10^{7}$ & 22.2 & 1 \\
\hline $\mathrm{HC}-6 \mathrm{O}$ & 6.00 & 5.84 & 5.80 & $5.7^{4}$ & $1.5 \times 10^{4}$ & $5.7 \times 10^{5}$ & $1.3 \times 10^{7}$ & 15.1 & 1 \\
\hline
\end{tabular}

TabIe 6 Assimilation of S.A.A by Yeasts

\begin{tabular}{|c|c|c|c|c|c|c|c|}
\hline S.A. A. & Rank & $\begin{array}{c}\text { SY }-16 \\
1234\end{array}$ & $\begin{array}{l}5 y-10 \\
12334\end{array}$ & S.A & Rank & $\begin{array}{c}5 Y-16 \\
1234\end{array}$ & $\begin{array}{l}5 Y-10 \\
1234\end{array}$ \\
\hline نّ̊ & \begin{tabular}{|l|}
$H C-5$ \\
$H C-10$ \\
$H C-30$ \\
$H C-60$
\end{tabular} & -1 & & $\sum_{\mathfrak{\Sigma}}^{c}$ & $\begin{array}{l}\text { TW 20 } \\
\text { TW640 } \\
\text { TW60 } \\
\text { TW } 80\end{array}$ & & \\
\hline O웡 & $\begin{array}{l}\text { RWISI05 } \\
\text { RWISIIIO }\end{array}$ & 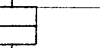 & & ๕. & $\frac{L W S-3}{L W S-5}$ & & \\
\hline 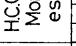 & \begin{tabular}{|l|} 
RWISI 140 \\
RWIS150
\end{tabular} & H & - & t্ & $\frac{L W S-8}{\text { LWS }-10}$ & & \\
\hline 일 & \begin{tabular}{|l|}
$\frac{O E-6}{}$ \\
$O E-10$ \\
$E m 810$ \\
$E m 820$ \\
\end{tabular} & 7 & & 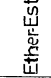 & $\begin{array}{l}\frac{L W I S-2}{L W I S-5} \\
L W I S-5 \\
L W I S-8 \\
L W I S-1\end{array}$ & & \\
\hline$\frac{\bar{v}}{\omega}$ & \begin{tabular}{|l|}
$200 d i-S$ \\
300 did- \\
40 di -5 \\
60 did-S \\
20 di -0 \\
\end{tabular} & & & & $\begin{array}{l}\text { GWS } 30 \\
\text { GWS } \\
\text { GWS } 30 \\
\text { GWS } 30 \\
\text { TPS } 303\end{array}$ & & \\
\hline$\stackrel{\square}{\square}$ & $\begin{array}{l}300 \mathrm{di}-0 \\
400 \mathrm{di}-0\end{array}$ & ] & & & $\begin{array}{l}\text { TPS } 305 \\
\text { TPS } 308\end{array}$ & & \\
\hline & $600 \mathrm{di}-0$ & & & & TPS 310 & & \\
\hline 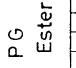 & \begin{tabular}{|l}
$P G S$ \\
$P G d i-S$ \\
$P G 0$ \\
$P G d i-O$
\end{tabular} & $\square$ & & & $\begin{array}{l}\text { OOSE-- } \\
\text { OISE- } \\
\text { OISE- } \\
\text { L } 151\end{array}$ & & \\
\hline 담 & $\frac{\mathrm{SP} 20}{\mathrm{SP} 40}$ & $I_{7}$ & & & $\frac{L 61}{L 62}$ & & \\
\hline in & \begin{tabular}{|l|} 
SP 60 \\
SP 80 \\
\end{tabular} & & & 与 & $\frac{664}{L 101}$ & & \\
\hline & & & & $\bar{a}$ & $\frac{F-68}{F-108}$ & & \\
\hline
\end{tabular}

\section{3. 結果}

コウボによる資化性のランクを示すと Table 6 のよ らになる。振とう培養は，かなり時間を要するのではじ め SY-16 で試験し，SY-16 による資化性の悪かったも のについてだけ SY-10 による試験を行った。従って表 の斜線部分は試験をしていないことを示す。

P.O, E, 硬化ヒマシ 油誘導体は E.O 付加モル 数の少 ない HC-5 や HC-10 は資化されれたが, 付加モル数の多 いHC-30，HC-60 は資化されにくかった。P.O.E.硬 化ヒマシ油モノイソステアレートもH.C.O.系と同じ 傾向を示した。P.O.E. 脂肪酸モノエステル，ジェステ ル,プロピレングリコールモノェステル, ジェステルにみ られるようにSY-16 はアテアリン酸エステルはよく資 化したが，オレイン酸エステルはほとんど資化出来なか った。しかしSY-10はオレイン酸エステルをよく資化し た。スパンは SY-16 によって SP $60>\mathrm{SP} 40>\mathrm{SP}$ $20>\mathrm{SP} 80$ の順に資化された。資化されなかった SP 80 (オレイン酸エステル) は SY-10によってょく資化 された。ッィーンは SY-16によって TW $60>\mathrm{TW}$ $20>\mathrm{TW} 40>\mathrm{TW} 80$ の順に資化された。P.O.E. ラウリルアルコールェーテルステアレート，P.O.E. ラ ウリルアルコールェーテルイソステアレートはともによ く資化された。カビによる資化性の悪かった P.O.E. グリセロールトリステアレート，P.O.E.トリメチロー ルプロパントリステアレートもSY-16によりよく資化さ れた。P.O.E.オクチルフェノールェーテルイソステア レートはカビ同様資化性が悪かった。プルロニック系の 
活性剤は全く資化されなかった。

以上まとめてみると,P.O.E. ラウリルアルコールイソ ステアレート, P.O.E. ステアリン酸ジェステル, P.O. E. グリセロールトリステアレートなどがよく資化され た。コウボでは菌株の差が顕著にあらわれた。SY 16 は ステアリン酸エステルはよく資化したがオレイン酸エス テルはほとんど資化出来なかった，しかしSY-10 はオレ イン酸エステルをよく資化した。

\section{5. バクテリアによる界面活性剤の資化}

\section{1. 供試菌}

No.16 Pseudomonas aeruginosa 製品分離菌 バクテリアについても製品分離菌23種の中から資化性 が強いと予想される菌 5 種類をえらび，まず Table. 1 の培地に寒天を添加した寒天培地を使い寒天平板培養法 で検討した。この方法で行らと, 活性凨菌が直接ふれ るのでュロニーの様子を意深く観察することにより, かなりの情報が得られた。

しかし資化性の有無は判定出来ても資化性をランクず けすることは出来なかった。そこで資化性の度合をラン クずけするために，コウボと同様に振とう培湌法による 検討を行った。

\section{2. 培養法と資化性の判定}

Table 1 に示した培地 $100 \mathrm{ml} 500 \mathrm{ml}$ 振とうフラス コに入れ, オートクレーブで滅菌, 冷却後あらかじめ前 培養した菌の懸濁水を一定量接種し, $30^{\circ} \mathrm{C} .120$ 回/分の 振とう条件で 1 週間培養, $\mathrm{pH}$ 経時変化, 乾燥菌体重量, 生菌数などる测定した。

菌の増殖を知るのに一般に使われている培養液の濁度 (O.D.)を测定子ることによって出来れば容易で便利だ が，下記の理由により利用出来ないことがわかった。

1. 活性剂の溶解度, 分散性などに差が尔るので培養液 の濁度に直接影響を与える。さらに活性剤の種類に よってば菌の自己融解が起り, 濁度に影響を与える ことが考えられる。

2. 培養液を遠心分離し菌体を集め洗浄する場合 アセトン，ジオキサンエエタノールなど水に溶ける 有機溶剤ば活性剤はよく洗い落すが, 菌体が凝集し 濁度の值がばらつく。ベンゼン, クロロホルム, エー テル, 䣷酸エチルなど水に溶けない溶剤は菌体への 影響は少ないが，水に再分散させた場合，溶けない 溶剂がわずかに残った活性珴により乳化され，新た な濁りを生じ濁度に影響を与える。
乾燥菌体重量はコウボと同様な方法で測定した。 生菌数は通常の稀釈平板法で測定した。

生菌数と $\mathrm{pH}$ 経時変化との関係をポリオキシェチレン ラウリルアルコールエーテルステアレートの E.O.5 モ ル付加物で示すと Fig.5 のよらになる。菌の増殖は 6 〜8時間目頃よりはじまり10〜20時間の間は対数的に増 殖している。そして菌の增殖に10時間位の遅れをもって

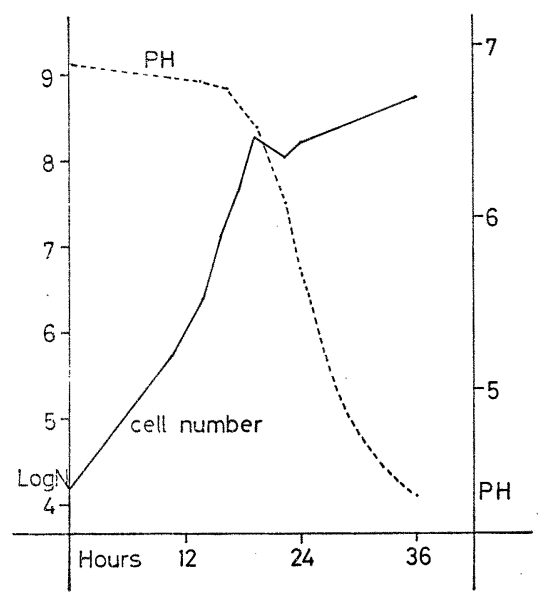

Fig. $5 \mathrm{PH}$-change of LWS-5 medium by time

菌の增殖曲線に対応して $\mathrm{pH}$ b急激に変化する。従って 培養液の $\mathrm{pH}$ 変化は菌の堌殖の結果として起るものと考え てよい。それ故, $\mathrm{pH}$ 経時変化は菌の增殖の結果として起 るものと考光てよい。それ故, $\mathrm{pH}$ 経時変化を测定する ことによって菌の増殖を予測することが出来る。基質 (添加する活性剤) が暴なるので菌の増殖と $\mathrm{pH}$ 変化が いつも対応して変化してゆくかどらかは問題点として残 る。しかし少くとも培善初期に $\mathrm{pH}$ が急に変化する場合 は菌が活性都它資化し增殖していると考えてよい。従っ

TabIe 7 Variation of assimilation by bacteria

\begin{tabular}{|c|c|}
\hline \multicolumn{2}{|c|}{$\begin{array}{l}\text { measure the optical density } \longrightarrow x \\
\text { opH-change of medium by time } \\
\text { oweight of dry cells } \\
\text { viable cell number }\end{array}$} \\
\hline Rank & pH-change \\
\hline $0:$ no assimilation & 6.90 \\
\hline $1:$ poor assimilation & $6.50 \sim 6.90$ \\
\hline 2 : fair assimilation & $5.50 \sim 6.50$ \\
\hline $3:$ good assimilation & $4.50 \sim 5.50$ \\
\hline 4 : excellent assimilation & $4.00 \sim 4.50$ \\
\hline
\end{tabular}


$て \mathrm{pH}$ 経時変化, 生菌数, 乾燥菌体重量のデーターをもと

に Table 7 に示すように 5 ランクにわけて判定した。

\section{3. 結果}

P.O.E. 硬化ヒマシ油誘導体の含んだ培地の $\mathrm{pH}$ 経時変 化を示すと Fig 6 のようになる。 4 種とも 1 日の誘導

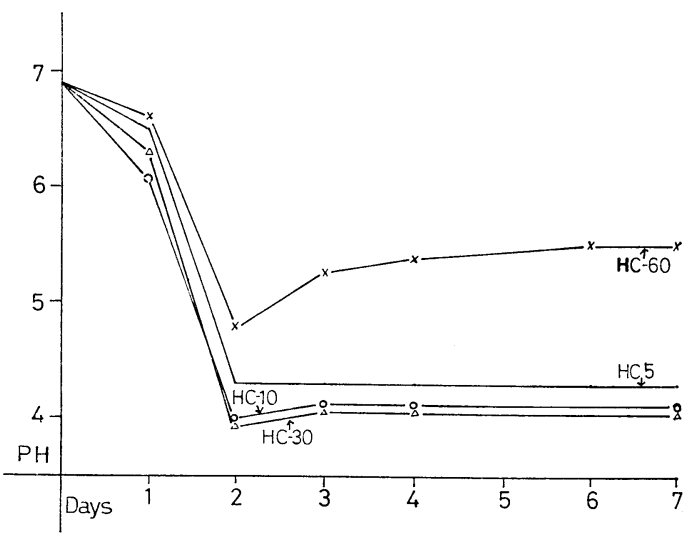

Fig. 6 PH-change of H.C. O. Der. medium by time 期の後, 急に $\mathrm{pH}$ が変化してゆき $\mathrm{HC}-60$ を除いては 2 日 目以降よりpHの変化は認められない。又生菌数も Table 8 に示すように $10^{4}$ のオーダーで接種したものが 1 日

TabIe 8 Assimilation of H.C.O. derivatives by No. 16

\begin{tabular}{|c|c|c|c|c|c|c|c|}
\hline \multirow{2}{*}{$\underbrace{\text { time }}_{\text {S.A.A. }}$} & \multicolumn{5}{|c|}{$\begin{array}{r}\text { viable cell numbers } \\
(\text { cells } / \mathrm{ml})\end{array}$} & \multirow{2}{*}{$\begin{array}{c}\text { weight of } \\
\text { dry cells } \\
\text { (7days,mg) }\end{array}$} & \multirow[t]{2}{*}{ riank } \\
\hline & 0 & 1 & 2 & 3 & 7 & & \\
\hline $\mathrm{HC}-5$ & $2.6 \times 10^{4}$ & $6.6 \times 10^{8}$ & $6.2 \times 10^{9}$ & $3.3^{\times 10^{2}}$ & $6.1 \times 10^{7}$ & 60.5 & 4 \\
\hline $\mathrm{HC}-10$ & $2.4 \times 10^{4}$ & $1.0 \times 10^{9}$ & $2.3 \times 10^{8}$ & $3.4 \times 10^{6}$ & $3.0 \times 10^{-3}$ & 65.1 & 4 \\
\hline $\mathrm{HC}-3 \mathrm{O}$ & $4.0 \times 10^{4}$ & $2.9 \times 10^{9}$ & $1.6 \times 10^{8}$ & $2.6 \times 10^{7}$ & $10^{3}$ & 76.7 & 4 \\
\hline $\mathrm{HC}-6 \mathrm{O}$ & $4.7 \times 10^{4}$ & $8.4 \times 10^{8}$ & $8.3 \times 10^{9}$ & $9.7 \times 10^{9}$ & $2.6 \times 10^{9}$ & 66.8 & 3 \\
\hline
\end{tabular}

で $10^{8}$ のオーダー迄增加している。これに対応して乾燥 菌体重量も60８0mg となり，いずれも No. 16 とよっ てよく資化されることがわかった。これらのデーターを もとに Table 7 に従ってランクずけすると Table 8 の ようになる。このようにして判定したバクテリアの資化 性を示すと Table 9 のようになる。Table 9 をみると わかるようにバクテリア（No.16）は，カビ，コウボより 資化性が強く, プルロニック以外の活性剂はカビ, コウ ボに資化されなかった OISE 系も含めて，よく資化され た。又プロピレングリコールステアリン酸モノエステ ル，ジェステル(P.G.S.P.G. dī-S) P.O.E.グリセロー
TabIe 9 Assimilation of S. A. A by Bactena (No.16)

\begin{tabular}{|c|c|c|c|c|c|}
\hline S.A.A. Rank & 12 & 3 & S.A.A. Rank & $\begin{array}{lll}1 & 2 & 3\end{array}$ & 4 \\
\hline $\mathrm{HC}-5$ & & & $200 \mathrm{di}-0$ & & \\
\hline $\mathrm{HC}-10$ & & & 300 di - 0 & & \\
\hline $\mathrm{HC}-30$ & & & 400di-0 & & \\
\hline $\mathrm{HC}-60$ & & & 600 di- 0 & & \\
\hline RWIS105 & & & PGS & & \\
\hline RWIS110 & & & PGdi-S & & \\
\hline RWIS140 & & & PGO & & \\
\hline RWI S150 & & & PGdi-O & & \\
\hline$O E-6$ & & & SP 20 & & \\
\hline $\mathrm{OE}-10$ & & & SP 40 & & \\
\hline Em 810 & & & SP 60 & & \\
\hline Em 820 & & & SP 80 & & \\
\hline $200 \mathrm{di}-\mathrm{S}$ & & & TW20 & & \\
\hline $300 \mathrm{di}-\mathrm{S}$ & & & TW40 & & \\
\hline $400 \mathrm{di}-\mathrm{S}$ & & & TW60 & & \\
\hline 600 di-S & & & TW 80 & & \\
\hline LWS - 3 & & & TPS303 & & \\
\hline LWS - 5 & & & TPS305 & & \\
\hline LWS - 8 & & & TPS308 & & \\
\hline LWS - 10 & & & TPS310 & & \\
\hline LWIS-2 & & & OISE $\cdot 3$ & & \\
\hline LWIS- 5 & & & $\frac{\text { OISE } \cdot 3}{\text { OISE - } 5}$ & & \\
\hline LWIS-8 & & & OISE - 5 & & \\
\hline LWIS -10 & & & OISE - 10 & & \\
\hline & & & L 31 & & \\
\hline GWS303 & & & L 61 & & \\
\hline GWS304 & & & L62 & & \\
\hline GW S305 & & & L 101 & & \\
\hline GW S306 & & & $L 64$ & & \\
\hline & & & $\mathrm{F} 38$ & & \\
\hline & & & $F 68$ & & \\
\hline & & & F108 & & \\
\hline
\end{tabular}

ルトリステアレート（GWS 303，GWS 304)にみられる ようにオレイン酸のエステルよりステアリン酸のエステ ルの方が資化されにくかった。

さらにスパン，ッイーンについてくわしくみると次の ようになる。Fig.7 に pH 経時変化 Fig.8 亿生菌数経時

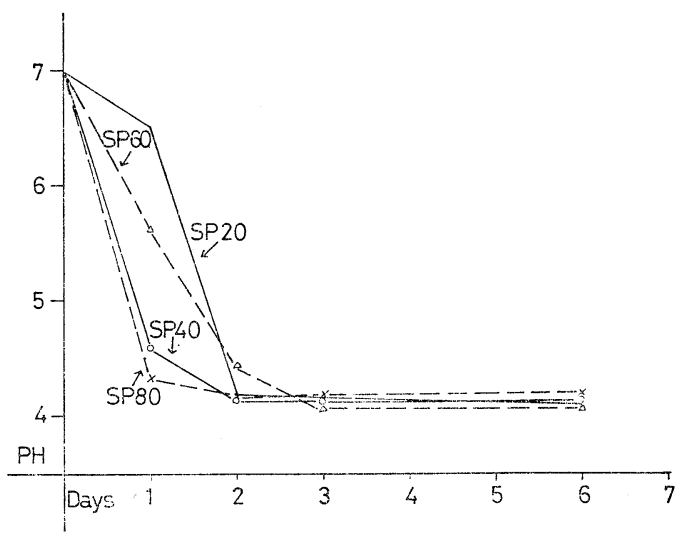

Fig. 7 pH-change of Span medium by time

変化を示した。スパンは 4 種ともよく資化された。乾燥 菌体重量には差があったが, $\mathrm{pH}$ 経時変化は 4 種の間には ほとんど差はなく，2 日目で $\mathrm{pH} 4$ 近く迄低下している。 $\mathrm{pH}$ 変化の早い SP. 80 は他のものと比べ乾燥菌体重量が 


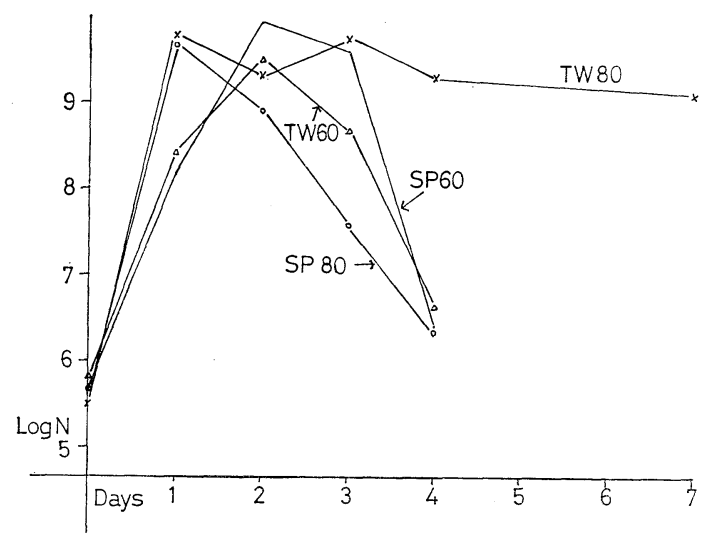

Fig. 8 Change of viable cell numbers in the medium by time

少なかった。これは菌の資化の速度が早いため $\mathrm{pH}$ が急 に低下し, pH 低下により菌の生育が阻害された結果と 考えられる。Fig. 7 と Fig. 8 をみると SP60, SP 80 ともに $\mathrm{pH}$ 経時変化と生菌数経時変化はよく対応して変 化している。従って乾燥菌体重量は少なくても $\mathrm{pH}$ 変化 の早い SP 80 は, 他のものよりさらによく資化される と考えられる。

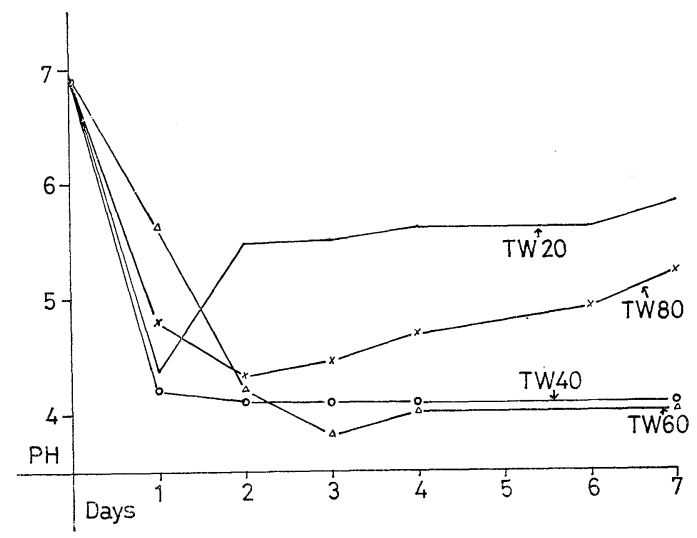

Fig. $9 \mathrm{pH}$-change of Tween medium by time

ツィーンの経時変化は Fig. 9 に示した。ツィーンも 4 種ともよく資化された。TW 20, TW 80 の系は $\mathrm{pH}$ が 一度 4 近く迄低下し, その後中性側へ戻る傾向 れた。この時の TW 80 の生菌数経時変化 Fig.8 をみ ると 1 日目から 1 週間目迄 $10^{9}$ のオーダーで菌が存在し ていた。このことを考えると資化が 2 段階で行なわれて いると思われる。2 日目以降 $\mathrm{pH}$ が変化しない系ではス パンと同様に生菌数は急に減少し 1 週間目では $10^{2}$ 以下
であった。

以上バクテリアについてまとめてみるとバクテリアは プルロニック 8 種を除いた残り 45 種の活性剤をすべてよ く資化した。

\section{6. 結果と考察}

カビ，コウボ，バクテリアの結果をまとめると Table 10 のよらになる。Table 10 をみるとわかるよらにプル ロニックは全く資化されない。そしてP.O.E.オクチル フェノールェーテルイソステアレートが資化されにくい 以外は, エステル型, エーテルェステル型活性剤は微生 物によく資化されることがわかった。プルロニックが資 化されないのは蹯水基, 親水基ともに資化されにくいプ ロピレングリコールとエチレングリコールであり，乙か もこれらがエーテル結合で結びついているためと考えら れる。

TabIe 10 Assimilation of S.A.A. by Microorganism

\begin{tabular}{|c|c|c|c|c|c|c|c|}
\hline S. A. & Fungi & Yeasts & Bacteria & S.A.A & Fungi & Yeasts & Bacteria \\
\hline $\mathrm{HC}-5$ & $x$ & $x$ & $x$ & 200 di-S & $x$ & $x$ & $x$ \\
\hline $\mathrm{HC}-10$ & $x$ & $x$ & $x$ & $300 \mathrm{di}-\mathrm{S}$ & $x$ & $x$ & $x$ \\
\hline $\mathrm{HC}-30$ & $x$ & $x$ & $x$ & $400 \mathrm{di}-\mathrm{S}$ & $\Delta$ & $x$ & $x$ \\
\hline $\mathrm{HC}-60$ & $x$ & $x$ & $x$ & $600 \mathrm{di}-\mathrm{S}$ & $\Delta$ & $x$ & $x$ \\
\hline RW1S105 & $x$ & $x$ & $x$ & $200 \mathrm{di}-0$ & $\bar{x}$ & $x$ & $x$ \\
\hline RWIS110 & $x$ & $x$ & $x$ & $300 \mathrm{di}-0$ & $x$ & $x$ & $\bar{x}$ \\
\hline RWIS140 & $x$ & $x$ & $x$ & 400di-O & $x$ & $x$ & $x$ \\
\hline RWI S150 & $x$ & $x$ & $x$ & $600 \mathrm{di}-0$ & $x$ & $x$ & $x$ \\
\hline$O E-6$ & $x$ & $x$ & $x$ & PGS & $x$ & $x$ & $x$ \\
\hline$O E-10$ & $x$ & $x$ & $x$ & PGdi-S & $x$ & $x$ & $x$ \\
\hline Em 810 & $x$ & $\Delta$ & $x$ & PGO & $x$ & $\bar{x}$ & $x$ \\
\hline \multirow[t]{5}{*}{ Em 820} & $\Delta$ & $x$ & $x$ & PGdi-S & $x$ & $x$ & $\bar{x}$ \\
\hline & & & & SP20 & $x$ & $\Delta$ & $x$ \\
\hline & & & & SP40 & $x$ & $\bar{x}$ & $x$ \\
\hline & & & & SP60 & $x$ & $x$ & $x$ \\
\hline & & & & SP80 & $x$ & $X$ & $x$ \\
\hline TW 20 & $x$ & $x$ & $x$ & TPS 303 & $x$ & $\frac{1}{x}$ & $x$ \\
\hline TW 40 & $x$ & $\Delta$ & $x$ & TPS 305 & $\frac{n}{x}$ & $x$ & $x$ \\
\hline TW 60 & $x$ & $x$ & $x$ & TPS 308 & $\triangle$ & $x$ & $\mathrm{y}$ \\
\hline TW 80 & $x$ & $x$ & $x$ & TPS 310 & $\triangle$ & $x$ & $x$ \\
\hline LWS - 3 & $\bar{x}$ & $x$ & $x$ & OISE - 3 & 0 & 0 & $x$ \\
\hline LWS - 5 & $x$ & $x$ & $x$ & OISE -5 & 0 & $\Delta$ & $x$ \\
\hline LWS - 8 & $x$ & $x$ & $x$ & OISE - 10 & $\Delta$ & $x$ & $x$ \\
\hline LWS - 10 & $x$ & $x$ & $x$ & L31 & 0 & 0 & 0 \\
\hline LWIS - 2 & $x$ & $x$ & $x$ & L61 & 0 & 0 & 0 \\
\hline LWIS - 5 & $x$ & $x$ & $x$ & L62 & 0 & 0 & 0 \\
\hline LWIS.- 8 & $x$ & $x$ & $x$ & L64 & 0 & 0 & 0 \\
\hline LWIS-10 & $x$ & $\triangle$ & $x$ & L101 & 0 & 0 & 0 \\
\hline GWS303 & $x$ & $x$ & $x$ & F38 & 0 & 0 & 0 \\
\hline GWS304 & $x$ & $x$ & $x$ & F68 & 0 & 0 & 0 \\
\hline GW 5305 & $\Delta$ & $x$ & $x$ & F108 & 0 & 0 & $\mathrm{O}$ \\
\hline GWS306 & $\Delta$ & $\bar{x}$ & $x$ & & & & \\
\hline
\end{tabular}

o no assimilation

$\Delta$ poor assimilation

$x$ good assimilation

さらに資化性を菌種別にみると Fig. 10 のようにな る。縦軸に菌の種類とランク, 横軸にそれぞれのランク を示した活性剤の数を示した。カビはランク 3 の活性剤 が多いがュウボはランク 2 の活性剤が多い。従ってカビ はコウボに比べ資化性がよい傾向がある。バクテリアは 


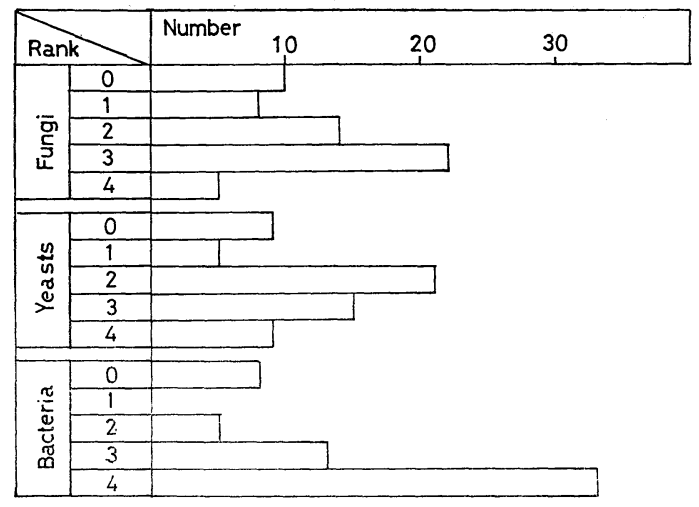

Fig. 10 Difference of S.A.A. assimilation by the type of microorganism

ランク 4 の活性剤が $50 \%$ 以上で Pseudomonas aeru ginosa No.16 は非常に資化性が強いことがわかった。 この菌は Ps. aeruginosa 特有のピオシアニンという 水溶性の色素を産生するので資化が進む従って培養液 が青緑色になる。一般に Ps. aeruginosa は土壊や水に 広く存在している。そして我々にとってもいやな污染菌
の代表的なものである。

この広い資化性を示したバクテリア No.16 でプルロ ニック以外のエーテル型活性剤約50種について試験した 結果について簡単にふれると次のようである。エステル 型, エーテルエステル型よりエーテル型活性剤は資化さ れにくいことがわかった。そしてェーテル型に於ては資 化性とエチレンオキサイド付加モル数との間に深い関連 が認められた。すなわち, エチレンオキサイド付加モル 数が増大するに従って資化されにくい傾向があった。そ して親油基のアルコールが直鎖ならェチレンオキサイド 付加モル数が 10 以下のものは資化された。

以上いろいろ述べてきたが活性剤が資化されてどうな るかについては当然知りたくなる。これについては付加 されているェチレンオキサイドのモル分布のない高純度 の活性剤を使用して検討している。又資化されないるの がいいのかどらかという問題は非常にむずかしい。微生 物に対して抵抗性の強い製品をつくるには資化されにく い原料を使用すればよい。しかしそらなると河川など自 然界の系に入った場合の環境問題があり一概に断言出来 ないのが現状である。

（昭和 51 年 2 月 20 日受理） 